\title{
The Effect of Sustainable Asymmetric Market Conditions on Returns \& Volatility in Stock Markets during a Global Financial Crisis
}

\begin{abstract}
Majid Imdad Khan', Aftab Ahmad ${ }^{2 *}$, Rana Shahid Imdad Akash ${ }^{3}$, Asif Mahmood $^{4}$, Ayyaz Ahmad ${ }^{5}$ and Shagufta Yasmin ${ }^{6}$, ${ }^{1}$ Department of Management Sciences, COMSATS University Islamabad, Lahore Campus, Lahore, Pakistan, ${ }^{2}$ Department of Electrical Engineering, NFC Institute of Engineering and Fertlizers Research (NFC-IEFR), Faisalabad, Pakistan, ${ }^{3}$ School of Business Management, NFC Institute of Engineering and Fertlizers Research (NFC-IEFR), Faisalabad, Pakistan, ${ }^{4}$ Department of Business Studies, Namal Institute, Mianwali, Pakistan, ${ }^{5}$ Department of Industrial and Systems Engineering, University of Hail, Hail, Saudi Arabia, ${ }^{6}$ School of Social Sciences and Humanities, University of Technology Management (UMT), Lahore, Pakistan, Email: ${ }^{1}$ scc.ranamajid@gmail.com, 2*aftabahmadrao@gmail.com, ${ }^{3}$ shahid.imdad@yahoo.com, 4asif.mahmood@ namal.edu.pk, 5ay.ahmad@uoh.edu.sa, ${ }^{6}$ s2018262012@umt.edu.pk;
\end{abstract}

Sustainable asymmetric market conditions' development and volatility in stock returns play a vital role in investment decisions during a global financial crisis. Rational investment decisions and portfolio diversification can have the optimum returns. However, portfolio diversification through Islamic stock returns is perceived as a model of safer flight than that of conventional stocks. In the present study, the GARCH $(1,1)$ - (Mean and Variance equations) has been employed to predict the impact of asymmetric market conditions on returns and volatility of Islamic stock markets (Dow Jones Islamic Market Malaysia (DJIM), Dow Jones Islamic Market Indonesia (JKII) and Dow Jones World Islamic Index (DJWI) Benchmark), and Conventional stock markets (Shanghai Stock Exchange (SSE-China), Bombay Stock Exchange (BSE-India) and Pakistan Stock Exchange (PSE-Pakistan), during the global financial crisis. The analysis reveals that the bullish effect was higher in all stock markets. Overall results suggested that Islamic stock markets have a sustainable impact of asymmetric market conditions on returns and volatility of Islamic stock markets \& conventional stock markets during the global financial crisis. The asymmetric market conditions in stock markets are strongly recommended for economic globalisation during a global financial crisis. 
Key words: Global Financial Crisis, Efficient Market Hypothesis, Pakistan Stock Exchange, Dow Jones World Islamic Index.

\section{Introduction}

Sustainable asymmetric market volatility during a global financial crisis (GFC) is a challenge for stock markets. The growth of a country depends on economic development, and stock markets play a vital role in making an economy sustainable (Gökgöz \& Atmaca, 2017; Kellner, Lienland \& Utz, 2019). Stock markets generate signals for investors who predict economic outcomes, whether found sustainable or volatile asymmetric (Chen, Zhong \& Chen, 2020 and Oikonomou, Platanakis \& Sutcli, 2018). Stock markets are perceived as an indicator of economic growth and economic function in a country (Bernardi \& Catania, 2018). Security trading to optimise the capital and accumulation of funds by investors are the primary functions that position the liquidity against invested money. The fall and rise in stock market prices impel the investors to adopt diversification decisions and ways of investment efficiently as well as effectively (Kellner, Lienland \& Utz, 2019 and Khan et al., 2019). Black (1976) and Christie (1982) for the first time introduced the well elucidated asymmetric volatility. However, an empirical experiment is evident on the asymmetric volatility of an asset even with zero leverage effect (Hens \& Steude, 2009 and Hasanhodzic \& Lo, 2011). In comparison, the alternative justifications on this phenomenon have been provided but still unexplained (Talpsepp \& Rieger, 2010; Bekaert \& Wu, 2000 and Jayasuriya et al., 2009).

The impact of shocks and volatility accelerates asymmetries in stock markets, raising the chances of a global financial crisis. The volatility in stock market returns resulted in economic association in it, and a more contagious effect in a period of a global financial crisis (GFC) (Hkiri, Hammoudeh \& Yarovaya, 2017). Despite the fact that the spread of a GFC increases from region to region (Dymski, 2005), however, the investment in Islamic stocks is preferred more than in conventional stocks during the GFC period (Dewandaru et al., 2014; Bin Mahfouz S. \& Ahmed, H, 2016 and Hkiri et al., 2017). On the other hand, several studies have rejected this hypothesis (Hammoudeh et al., 2014; Ajmi et al., 2014; Jebran et al., 2017; Shahzad et al., 2017). But on practical grounds, the global capital markets have witnessed an expansion in Islamic securities during the last decades and are considered filtered assets. The shariacompliant assets not only expanded in Islamic emerging markets but further in conventional capital markets. The international financial system got innovated with the introduction of Islamic stocks and bonds. The Islamic stock is predicted better than traditional stock and hence more profitable (Narayan \& Bannigidadmath, 2015; Aloui et al., 2016). But remarkably, the co-movement of the stock market $\&$ behaviour (shocks) remained a controversial issue in finance literature (Aloui \& Hkiri, 2014). But the fact remains that stock markets slow down the economy, cause distress, and increase volatility (Zhou et al., 2012; Bissoondoyal et al., 2018; Roni et al., 2018; Sehgal et al., 2018; Kirkulak, Uludag \& Khurshid, 2019 and Sznajderska, 2019). 
There are several studies on asymmetric volatility of conventional stocks but limited to Islamic stocks, yet, none of the work has been conducted to explore asymmetric shocks on Islamic stocks. In this regard, this study attempts to fill the gap by estimating the asymmetric volatile effect of shocks on Islamic stock markets and comparing it with conventional stock markets. Particularly, the study investigates the performance of Islamic stock returns and their volatility with regard to conventional stock markets and by analysing sustainable asymmetric effects of shocks during the period of a global financial crisis. This study explores an explanation on proofs that disclose that the stock market is asymmetric. Investors are influenced more when the returns are found negative (Engelberg \& Parsons 2016). Hence, the analysis of this study focuses on the following logic, as highlighted by Andrei \& Hasler (2015): since consideration is relevant to volatility, the rise of asymmetric volatility depends on asymmetric attention. Moreover, if there is no attention of investors to firm or market, then there is no asymmetric behaviour. Hence, a higher level of attention should create higher asymmetry and a higher level of volatility asymmetry.

The remainder of this paper is divided into the following sections. Section 2 is based on a literature review. Section 3 explores the data and methodology used for data analysis. Section 4 investigates the results and discussion on analysis. Section 5 is on concluding remarks and recommendations.

\section{Literature Review}

The theoretical framework of an efficient market hypothesis (EMH) explores a fair game model (Fama, 1970). The random behaviours of stock indicate that stock prices are unpredictable, and available information is fully absorbed by stock returns. There are three types of EMH; a weak form of efficiency, a semi-strong form of efficiency and a strong form of efficiency. The random walk model represents that the stock prices floated independently over random parameters. The theory of EMH particularly extracts volatility of security returns, which negate autoregressive process to explore the possible expectedly existence of volatility.

Much importance has been given to time series and linear models (Brooks, 2008). The phenomenon is explained into three types of parameters. Leptokurtosis: The fat-tailed distribution of the tendency of returns shows a surplus of average peak values; Clustering volatility/Pooling: The trends or volatility in financial markets occur in clusters. The larger the sign in terms of negative/positive, the larger the returns expectedly or vice versa (Mandelbrot, 1963); The Leverage Effect: The volatility for leverage can be noticed in an increase of a larger price or magnitude of the same level. The financial data are assessed through nonlinear (ARCH $(1,1)$ GARCH $(1,1)$ models (Brooks, 2008).

The financial theoretical framework suggested that the association between the variables could be explored but restricted to financial theory. The closure of linearity $\&$ nonlinearity is decided through the distribution of data or magnitude significantly featured. The researchers explained many options for applying nonlinear models to financial series. The asymmetric trends could 
be explored through asymmetric models in the way of the support of mean \& variance. The available theories are evident for motivating to explore the problems, and may provide a solution through extended attributes for stock markets.

\subsection{Hypotheses Development}

The concept of the capital asset pricing model was initially proposed by (Sharp, 1964; Lintner, 1965). This model was based on optimisation of mean and variance phenomenon (Markowitz, 1952). The theoretical framework suggested that the risk of non-diversifiable assets is proportional to returns of an individual asset expectedly and the above risk-free rate. The theory further explored that all available portfolios comprise returns of an asset and should be measured in equity markets. The model based on risk factors for macroeconomic factors was proposed by Ross, Roll and Chen (1986). Moreover, Fama and French (1993) introduced the extended model CAMP, SMB \& HML for measuring the risk factor for macroeconomics factors. Later Carhart, (1997) further modified it into a three-factor model, adding a momentum factor.

As far as the average returns used to explore the performance estimation of stocks regarding previous years is concerned, the volatility is included in the asset pricing model being an extended parameter. This approach is explained as modeling of asset pricing \& inclusion of conditional volatility. Many researchers have explored the asymmetric effect by various techniques. The results showed that the asymmetric effect could predict stock returns, GARCH $(1,1)$, ASAR E-GARCH $(1,1)$ and models used (Lobo, 2000). The supportive mean reversion behaviour of the stock to real interest rate was explored using TAR, EQ-TAR, C-TAR, MTAR, SEQ-TAR in the UK (Coakley \& Fuertes, 2002). The asymmetries in the financial series are cyclical in nature, explored through GARCH $(1,1)$ \& E-GARCH $(1,1)$ models (Koutmos \& Martin, 2003). Many other researchers have tested asymmetric behaviour by applying different GARCH modeling and found mixed results (Joseph \& Vezos, 2006; Ferreira, Menezes \& Mendes, 2007; Wang \&Thi, 2010; Brooks et al., 2010; Dean, Faff, and Loudon, 2010; Haughton \& Iglesias, 2012; Fadiran \& Ezeoha, 2012).

The asymmetric volatility in financial markets is dominated to cluster in such a way that a period of volatility is explored to persist upon the market returns to normality. Hence, the researchers explained that a change in stock volatility is predicted as random and time-variant. The difference in stock market returns and volatility is crucial to understand. Market segmentation is essential to investigating potential benefits significantly from investment in emerging markets. The facts have been possibly a great deal to look into (Errunza, 1994; BenZion et al., 1996; Friedman, 1998). The stock market volatility of London, New York and Tokyo has been investigated, to observe the impact of bad news and good news using the EGARCH $(1,1)$ model on daily returns (Koutmos \& Booth, 1995). They have observed that asymmetric market volatility is more prominent, but the effect found is inconsistent in the 
source of risk for nonmarket (Braun et al., 1995). The inconsistency and risk in stock markets explore the linkages between stock markets and the mark of a financial crisis.

A bulk of literature covers the scope of the financial crisis and explores the asymmetric linkages of stock markets. Some studies considered individual countries among exceptionally focused on asymmetric volatility in international stock markets (Michel, 2011 and Liow, 2012). The financial crisis has influenced different regions or globally but the degree of asymmetric volatility among stock markets is found differently. Research has been conducted to observe the effect of the financial crisis and the existence of co-movement in stock markets of countries, i.e., Brazil, China, India, Russia and the US (Aloui, Aissa \& Nguyen, 2011). The stock markets were predicted more integrated during the global financial crisis (GFC), and gold prices enhanced the performance of stock markets of BRICS countries, respectively (Yamani \& Swanson, 2014 and Mensi, Hammoudeh, Yoon, and Nguyen, 2016). The asymmetric effect is largely pronounced when all the sectors are considered (Baruník, Kocenda \& Vacha, 2016). Most of the studies are conducted to explore the effect of asymmetric market conditions on returns of conventional stocks. But this study is conducted to examine the impact of asymmetric market conditions on Conventional stock as well as on Islamic stocks and during the period of a global financial crisis (GFC). The asymmetric effect can be observed to evaluate the performance of stock markets (Conventional and Islamic) during the period of a global financial crisis (GFC) with the help of the hypothesis below:

$\mathrm{H}_{1}$ : Asymmetric market conditions have a larger influence on returns and volatility of Conventional Stock Markets during the global financial crisis.

$\mathrm{H}_{2}$ : Asymmetric market conditions have less influence on returns and volatility of Islamic stock markets during the global financial crisis.

\section{Data and Methodology}

\subsection{Data}

The data for this study comprise stock market prices (Islamic \& Conventional), Shanghai Stock Exchange (SSE-China), Bombay Stock Exchange (BSE-India), Pakistan Stock Exchange (PSE-Pakistan) and Dow Jones Stock Exchange for Malaysia (DJIM), Jakarta Islamic Stock Market for Indonesia (JKII) \& Dow Jones World Islamic Index (DJWI) respectively. The data were collected from yahoo finance and DataStream websites for the period from 04 Jan, 2005 to $30^{\text {th }}$ Dec, 2015, which includes the period of a global financial crisis (GFC). E-Views, Stata and Ox-Matrix software were used.

\subsection{Measurement of Stock Returns}

\subsubsection{Calculation of Returns}

The returns are calculated as under: 
International Journal of Innovation, Creativity and Change. www.ijicc.net

Volume 15, Issue 5, 2021

$$
X_{t}=\ln \left(\frac{P_{t}}{P_{t-1}}\right)
$$

Whereas, $P_{t}$ denotes as the price of stock market index at time t. $P_{t-1}$ is price of stock market index at previous times.

\subsubsection{Returns, Volatility \& Asymmetries in Markets}

The model for investigating the impact of information asymmetries on returns and volatility is employed as under.

$X_{t}=\alpha_{0}+\beta X_{t-1}+\gamma \delta_{t}^{2}+\varphi_{1}(D)_{t}+\varepsilon_{t}$

Whereas, the $X_{t}$ indicates, returns at time t, $\alpha_{0}$ as constant, $\beta, \gamma \& \varphi$ are coefficients and slopes. $\delta_{t}^{2}$ denotes as variance $\& \varepsilon_{t}$ as error term at time t, the value of $\varphi$ if found significantly positive, then the returns for bullish market perceived as higher. The equation is modeled as under.

$v_{t}=\gamma_{0}+\sum_{i=1}^{p} \delta_{i} v_{t-1}+\sum_{j=1}^{q} \gamma_{j} \mu_{t-j}^{2}+\sum_{k=1}^{m} \mu_{k} D_{k}$

Whereas, Bullish is equal to " 1 " otherwise " 0 " as dummies. If there would be a significant value of $\delta$ then that means that the volatility is persistent to the volatility in the next period.

\section{Results \& Discussion}

The data for all the conventional and Islamic stock market returns were used from Jan 04, 2005 to Dec 30, 2015, covering the period of the global financial crisis. The J.B stands for Jarque Bera statistics, used for measuring normality. The Shanghai Stock Exchange (SSE), Bombay Stock Exchange (BSE), Pakistan Stock Exchange (PSE), Dow Jones Islamic Index Malaysia (DJIM) and Jakarta Islamic Index (JKII). The stocks of PSE generated higher average returns but SSE and BSE stocks remained riskier, as shown in table 1.

Table 1. Estimation of Descriptive Statistics of SSE, BSE, PSE, DJIM and JKII

\begin{tabular}{lllcccc}
\hline $\begin{array}{l}\text { Indexes } \\
\text { value }\end{array}$ & Mean (\%) & Std. Dev. & Skewness & Kurtosis & J. B & P- \\
\hline SSE & 0.0015 & 0.0643 & -3.7957 & 34.5831 & 5715.2520 & 0.0000 \\
BSE & -0.0007 & 0.0382 & 1.0529 & 6.7547 & 100.3805 & 0.0000 \\
PSE & 0.0002 & 0.0278 & 0.6135 & 8.4780 & 170.7001 & 0.0000 \\
DJIM & -0.0026 & 0.0265 & -1.1784 & 9.8351 & 283.1481 & 0.0000 \\
JKII & -0.0276 & 0.3443 & -6.0512 & 66.5018 & 22635.9800 & 0.0000 \\
\hline
\end{tabular}

DJWI 
SSE, BSE and PSE are negatively skewed but DJIM remained positively skewed. The Jarque Bera test for normality confirms exodus from normality regarding all the market returns, as shown in the graph below (figure 1). The data were collected from Yahoo Finance, Bloomberg and investing.com websites.
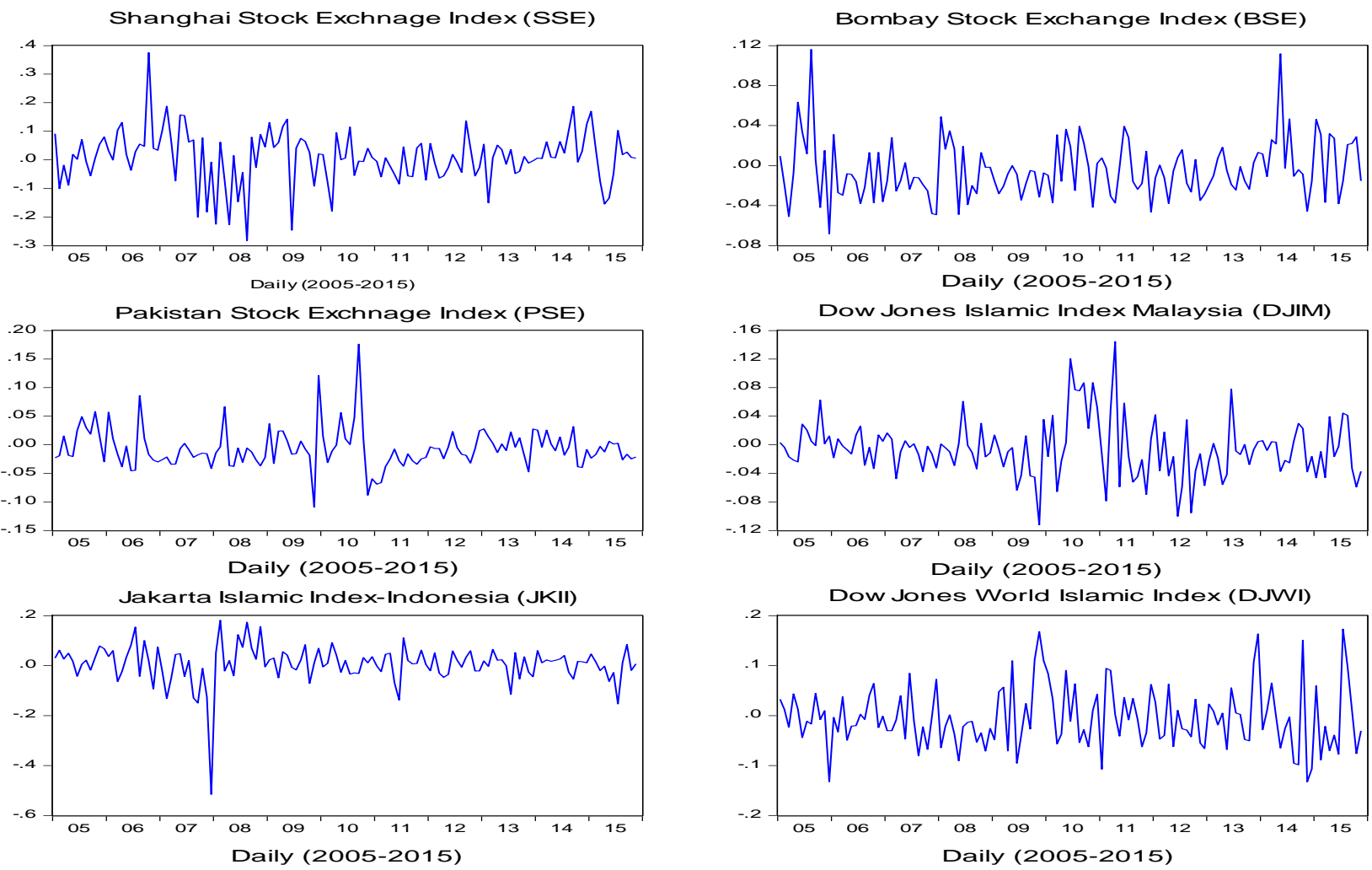

Figure 1: The Jarque Bera test for normality

Table 2 describes the results of returns, volatility and asymmetric market conditions for SSE, BSE, PSE (Conventional markets) \& DJIM, JKII, DJWI (Islamic Markets). The bearish and bullish effect in the market observed by the value of $\theta_{1}$ if found significantly positive. The results predicted that the returns of SSE-China were found higher during the bullish period. 
International Journal of Innovation, Creativity and Change. www.ijicc.net

Volume 15, Issue 5, 2021

Table 2. Estimation of GARCH $(1,1)$ in Mean for Returns, Volatility \& Asymmetric Market Conditions (SSE, BSE, PSE, DJIM, JKII \& DJWI), the determination of the sustainable impact of Asymmetric Market Conditions on Returns during the Global Financial Crisis (GFC).

\begin{tabular}{|c|c|c|c|c|c|c|c|}
\hline \multirow[b]{2}{*}{ Statistics } & \multirow[b]{2}{*}{ Parameters } & \multicolumn{3}{|c|}{ Conventional Stocks } & \multicolumn{3}{|c|}{ Islamic Stocks } \\
\hline & & SSE(China) & BSE(Ind) & PSE(Pak) & DJIM(Mal) & JKII(Indo) & DJWI \\
\hline \multirow{8}{*}{$\begin{array}{c}\text { Mean } \\
\text { Equation }\end{array}$} & $\alpha_{0}$ & -0.02041 & -0.009886 & -0.009322 & -0.007753 & -0.02021 & -0.003165 \\
\hline & $\boldsymbol{p}$-value & $<0.00001$ & $<0.00001$ & $<0.00001$ & $<0.00001$ & $<0.00001$ & $<0.00001$ \\
\hline & $\beta$ & 0.024774 & 0.042587 & 0.056823 & 0.089798 & 0.068488 & 0.210699 \\
\hline & $\boldsymbol{p}$-value & 0.4451 & 0.0355 & 0.0042 & $<0.00001$ & $<0.00001$ & $<0.00001$ \\
\hline & $\gamma$ & 2.93924 & -0.255861 & 0.028541 & 3.430209 & 4.306776 & 0.082884 \\
\hline & $\boldsymbol{p}$-value & 0.5308 & 0.949 & 0.3385 & 0.4093 & 0.2249 & 0.0003 \\
\hline & $\theta_{1}$ & 0.030395 & 0.029769 & 2.936358 & 0.023061 & 0.029732 & 0.00681 \\
\hline & p-value & $<0.00001$ & $<0.00001$ & $<0.00001$ & $<0.00001$ & $<0.00001$ & $<0.00001$ \\
\hline \multirow{6}{*}{$\begin{array}{l}\text { Variance } \\
\text { Equation }\end{array}$} & $\gamma_{0}$ & $5.78 \mathrm{e}-04$ & 0.00000359 & 0.00000843 & 0.0000337 & 0.0000848 & -0.00000489 \\
\hline & $\boldsymbol{p}$-value & $<0.00001$ & $<0.00001$ & $<0.00001$ & $<0.00001$ & $<0.00001$ & 0.523 \\
\hline & $\delta$ & 0.089044 & 0.983875 & 0.925576 & 0.0082337 & 0.005284 & 0.000563 \\
\hline & $\boldsymbol{p}$-value & $<0.00001$ & $<0.00001$ & $<0.00001$ & $<0.00001$ & $<0.00001$ & $<0.00001$ \\
\hline & $\gamma_{1}$ & 0.998954 & 0.216039 & 0.232095 & 0.000706 & 0.009547 & 0.000571 \\
\hline & $\boldsymbol{p}$-value & $<0.00001$ & $<0.00001$ & $<0.00001$ & $<0.00001$ & $<0.00001$ & $<0.00001$ \\
\hline \multirow{3}{*}{$\begin{array}{l}\text { Diagnostic } \\
\text { Testing }\end{array}$} & $\begin{array}{l}\text { AIC } \\
- \text { Statistics }\end{array}$ & -5.98796 & -6.230495 & -6.26734 & -6.89571 & -6.34758 & -6.31862 \\
\hline & $\begin{array}{l}\text { SIC - } \\
\text { Statistics }\end{array}$ & -5.92893 & -6.214608 & -6.24831 & -6.8882 & -6.328931 & -6.29523 \\
\hline & $\begin{array}{l}\text { Log } \\
\text { - Likelihood }\end{array}$ & 8098.758 & 8288.339 & 8333.351 & 9085.23 & 8428.876 & 5547.827 \\
\hline
\end{tabular}

The asymmetric pattern observed as when the value of $\theta_{1}$ predicted positive. This situation explores that the volatility of current prices is influenced by past prices. The volatility in the next period was found persistent as per the past period and calculated by the significant value of $\delta$. The asymmetries in markets were observed significantly by the value of $\gamma_{1}$. The returns of BSE-India were found higher during a bearish period as the value of $\theta_{1}$ found positive. The volatility in current market price is influencing by past prices and found to be asymmetric in behaviour. The volatility in the next period was persistent $\&$ significant, observed by the value of $\delta$. The markets are exploring asymmetric behaviour, observed through the significant value of $\gamma_{1}$.

The estimation of volatility for measuring the bullish effect for the DJIM stock market index was observed by the value of $\theta_{1}$. The value of $\theta_{1}$ was found to be significantly positive and the returns higher in the bullish period than the bearish period. The asymmetric behaviour for this market was observed and the volatility in the next period was found persistent by the value of $\delta$. The stock market of JKII and its behaviour remained significant and asymmetric, observed by the value of $\gamma_{1}$. The bullish effect for the JKII stock market was found to be significant \& positive, observed through the value of $\theta_{1}$. The returns were higher in the bullish 
International Journal of Innovation, Creativity and Change. www.ijicc.net

Volume 15, Issue 5, 2021

period than the bearish period. The volatility in the current price of the stock market is influencing the past price of the stock market as the value of $\theta_{1}$ found positive and the volatility in the next period was found persistent by the value of $\delta$. The bullish effect for DJWI stock markets was estimated by the value of $\theta_{1}$ and found positive, as well as higher in bullish period than bearish period. Overall results predicted that returns in the bullish period were found to be higher than that of bearish period regarding both the Islamic stock markets and Conventional stock markets. The impact of the asymmetric market condition on returns for all the stock markets was found persistent that explored that the volatility in the next period contributed, but less for Islamic stock markets than Conventional stock markets during the period of the global financial crisis (GFC).

Table 3 illustrates the results of GARCH $(1,1)$ in mean regarding exposition of volatility effect as bullish \& bearish stock markets in SSE, BSE, PSE, DJIM, JKII \& DJWI. The volatility of returns as a bullish stock market predicted higher with low volatility and a strong risk-return relationship.

Table 3. Estimation of GARCH $(1,1)$ in Mean for Returns, Volatility \& Asymmetric Market Conditions (SSE, BSE, PSE, DJIM, JKII \& DJWI), determination of the sustainable impact of Asymmetric Market Condition on Volatility during the Global Financial Crisis (GFC).

\begin{tabular}{|c|c|c|c|c|c|c|c|}
\hline \multirow[b]{2}{*}{ Statistics } & \multirow[b]{2}{*}{ Parameters } & \multicolumn{3}{|c|}{ Conventional Stocks } & \multicolumn{3}{|c|}{ Islamic Stocks } \\
\hline & & SSE(China) & BSE(Ind) & PSE(Pak) & DJIM(Mal) & JKII(Indo) & DJWI \\
\hline \multirow{6}{*}{$\begin{array}{c}\text { Mean } \\
\text { Equation }\end{array}$} & $\alpha_{0}$ & 0.003679 & 0.088493 & 0.088807 & 0.021058 & 0.070208 & 0.0000902 \\
\hline & $\boldsymbol{p}$-value & $<0.00001$ & $<0.00001$ & $<0.00001$ & $<0.00001$ & $<0.00001$ & 07596 \\
\hline & $\boldsymbol{\beta}$ & 0.04683 & 0.021071 & 0.047689 & 0.063298 & 0.059946 & 0.345183 \\
\hline & $\boldsymbol{p}$-value & 0.2164 & 0.3695 & 0.0004 & $<0.00001$ & $<0.00001$ & $<0.00001$ \\
\hline & $\gamma$ & -2.7262 & -540.2027 & -514.4865 & -133.565 & -402.6658 & -0.38079 \\
\hline & p-value & 0.4886 & $<0.00001$ & $<0.00001$ & $<0.00001$ & $<0.00001$ & 0.7858 \\
\hline \multirow{8}{*}{$\begin{array}{l}\text { Variance } \\
\text { Equation }\end{array}$} & $\gamma_{0}$ & 0.000208 & 0.000323 & 0.000284 & $1.46 \mathrm{E}-05$ & 0.00028 & -0.00000224 \\
\hline & $\mathrm{p}$-value & $<0.00001$ & $<0.00001$ & $<0.00001$ & $<0.00001$ & $<0.00001$ & $<0.00001$ \\
\hline & $\delta$ & 0.78369 & 0.009128 & -0.003298 & 0.0198246 & 0.000258 & 0.000465 \\
\hline & $\mathrm{p}$-value & $<0.00001$ & 0.7618 & 0.3655 & 0.0844 & 0.905 & $<0.00001$ \\
\hline & $\gamma_{1}$ & 0.26426 & -0.000852 & 0.000847 & 0.027746 & 0.002258 & 0.870775 \\
\hline & p-value & $<0.00001$ & 0.2247 & 0.376 & $<0.00001$ & $<0.00001$ & $<0.00001$ \\
\hline & $\mu_{1}$ & -0.000021 & -0.0000709 & -0.0000578 & -0.000029 & -0.000018 & -0.000022 \\
\hline & $\boldsymbol{p}$-value & $<0.00001$ & $<0.00001$ & $<0.00001$ & $<0.00001$ & $<0.00001$ & $<0.00001$ \\
\hline \multirow[b]{3}{*}{$\begin{array}{l}\text { Diagnostic } \\
\text { Testing }\end{array}$} & $\begin{array}{l}\text { AIC } \\
- \text { Statistics }\end{array}$ & -5.48233 & -5.89356 & -5.98754 & -6.80869 & -6.027958 & -6.25459 \\
\hline & $\begin{array}{l}\text { SIC - } \\
\text { Statistics }\end{array}$ & -5.46529 & -5.87653 & -5.94275 & -6.79068 & -6.00089 & -6.22929 \\
\hline & $\begin{array}{l}\text { Log } \\
\text { - Likelihood }\end{array}$ & 7399.423 & 7866.943 & 8075.105 & 8982.376 & 8157.389 & 5498.842 \\
\hline
\end{tabular}


The volatility regarding bearish markets was found to be higher than bullish markets, explored by the negative values of $\mu_{1}$ regarding all the markets, i.e., SSE, BSE, PSE, DJIM, JKII \& DJWI but minimal in Islamic stocks compared to conventional stocks as the magnitude was lower. This indicates that the returns in bullish stock markets are found to be higher at the time of low volatility. This indicates a better risk-return relationship. The overall results predicted that there was a bullish effect for all the Islamic stock markets as well as Conventional stock markets, observed through the negative values of $\mu_{1}$ which explored higher with low volatility. This examined that there is a better risk-return relationship. The impact of the asymmetric market condition on volatility in Islamic stock markets was perceived as lower than conventional stock markets during the global financial crisis (GFC).

\section{Conclusion}

The theory of asymmetric market conditions plays a vital role in stock volatility and introduces a concept of mean-variance portfolio optimisation during the period of a global financial crisis. The popular normality assumption for financial series and asymmetric market conditions based on mean-variance is far from valid due to skewness and clustering of volatility. The optimisation of mean-variance devalues the risk in a way that variance is considered an indicator to control all risks associated with an investment. The presence of asymmetries in financial time series produces unfavourable signals to markets. The asymmetric market conditions challenge the efficiency of markets and impact the perception of investors to make decisions of investment. The confidence of investors may enhance the market and the improvements in markets increase trust, which reduces the frictions and the anomalous behaviour of markets. The study investigates the impact of the asymmetric market conditions on returns \& volatility for both the Islamic stock markets and conventional stock markets during a global financial crisis. We used $\operatorname{GARCH}(1,1)$ (Mean \& Variance equation) to predict the bullish/bearish impact on stock markets. The bearish and bullish effect is found in the markets but the bullish effect is higher. The volatility in the next period was found persistent $\&$ significant. The markets are exploring asymmetric behaviour. The returns were higher in the bullish period than the bearish period. The volatility of returns as the bullish stock market predicted, is higher with low volatility and a strong risk-return relationship. The impact of asymmetric market conditions on returns \& volatility for Islamic stock markets was found less than conventional stock markets during a global financial crisis. It means that the asymmetric market volatility can be hedged during financial turmoil. In fact, choices of asymmetric market conditions on returns and volatility represent the governance tools that preserved the efficiency of governance and enhance the ability to determine value creation. The value creation may provide a way to diversify the risk for optimal capital structure. In this regard, the determination of the impact of asymmetric market conditions during the global financial crisis on returns and volatility of stocks enhance proficiency to achieve optimal investment decisions. 
International Journal of Innovation, Creativity and Change. www.ijicc.net

Volume 15, Issue 5, 2021

\section{REFERENCES}

Ajmi, A. N.; Hammoudeh, S.; Nguyen, D. K.; \& Sarafrazi, S. How strong are the causal relationships between Islamic stock markets and conventional financial systems? Evidence from linear and nonlinear tests. Journal of International Financial Markets, Institutions and Money 2014, 28, 213-227.

Aloui, C.; Hkiri, B.; Lau, C.; K.; M.; \& Yarovaya, L. Investors' sentiment and US Islamic and conventional indexes nexus: a time-frequency analysis. Finance Research Letters 2016.

Andrei \& M.; Hasler. Investor attention and stock market volatility'. Review of Financial Studies 2015, 28(1):33-72.

Bekaert \& G. Wu. Asymmetric volatility and risk in equity markets. Review of Financial Studies 2000, 13(1):1-42.

Ben-Zion, U.; Choi, J.; J. and Hauser, S. The price linkages between country funds and national stock markets: evidence from cointegration and causality tests of Germany, Japan and UK funds”, Journal of Business Finance and Accounting 1996, 23, 1005-1017.

Bernardi, M.; Catania, L. Portfolio optimization under flexible dynamic dependence modelling. J. Empir. Financ. 2018, 48, 1-18.

Bin Mahfouz, S.; \& Ahmed, H. Shariah investment screening criteria: A critical review. Journal of King Abdulaziz University: Islamic Economics 2016, 27(1), 111-145.

Bissoondoyal-Bheenick E.; Brooks R.; et al. Volatility spillover between the US, Chinese and Australian stock markets. Aus J Manage 2018, 43: 263-285.

Black, Studies of stock price volatility changes. Proceedings of the 1976 Meetings of the Business and Economic Statistics Section. American Statistical Association 1976, 177 181.

Braun, P.; A.; Nelson, D.; B. and Sunier, A.M. Good news, bad news, volatility, and betas. Journal of Finance 1995, 50, 1575-1603.

Brooks, C. Modeling volatility and correlations. Introductory Econometrics for Finance, 2nd Edition, Cambridge University Press, UK 2008.

Brooks, D.; R., Lorio, D.; A., Fry, T. and Joymungul, Y. Asymmetry and time variation in exchange rate exposure: An investigation of Australian stock returns. International Journal of Commerce and Management 2010, 1-33.

Carhart, M.; M. On Persistence in Mutual Fund Performance. The Journal of Finance 1997, 52, 57-82. 
International Journal of Innovation, Creativity and Change. www.ijicc.net

Volume 15, Issue 5, 2021

Chen, B.; Zhong, J.; Chen, Y. A hybrid approach for portfolio selection with higher-order moments: Empirical evidence from Shanghai Stock Exchange. Expert Syst. Appl. 2020, $145,113104$.

Christie, The Stochastic Behavior of Common Stock Variances: Value, Leverage and Interest Rate Effects'. Journal of Financial Economics 1982, 10(4):407-432.

Coakley, J and Fuertes, M.; A. Asymmetric dynamics in UK real interest rates", Applied Financial Economics 2002, 12, 379-387.

Dean, G.; W, Faff, W.; R and Loudon, F.; G. Asymmetry in return and volatility spillover between equity and bond markets in Australia. Pacific-Basin Finance Journal 2010, 18, 272-289.

Dewandaru, G.; Rizvi, S.; A. R. Masih, R.; Masih, M.; \& Alhabshi, S.; O. Stock market comovements: Islamic versus conventional equity indices with multi-timescales analysis. Economic Systems 2014, 38(4), 553-571.

Dymski, G.; A. Financial globalization, social exclusion and financial crisis. International Review of Applied Economics 2005, 19(4), 439-457.

Engelberg \& C.; A. Parsons. Worrying about the Stock Market: Evidence from Hospital Admissions'. Journal of Finance 2016, 71(3):1227-1250.

Errunza, V.; R. Emerging markets: some new concepts", The Journal of Portfolio Management $1994,20,82-87$.

Fadiran, O.; G.; and Ezeoha, A. South African market volatility, asymmetric and retail interest rates pass through. South African Journal of Economics 2012, 80, 157-180.

Fama E. (1970) "Efficient Capital Markets: A Review of Theory and Empirical Work", Journal of Finance, 25, 383-417.

Fama, E.; F and French, K.; R. (1993)"Common Risk Factors in the Returns on Stocks and Bonds", Journal of Financial Economics, Volume 33, No. 1, pp. 3-55.

Ferreira, Menezes and Mendes. Asymmetric conditional volatility in international stock markets", Physica A 2007, 382, 73-80.

Freimann, E. Economic integration and country allocation in Europe", Financial Analysts Journal 1998, 54, 32-41.

Gökgöz, F.; Atmaca, M.E. Portfolio optimization under lower partial moments in emerging electricity markets: Evidence from Turkey. Renew. Sustain. Energy Rev. 2017, 67, 437449. 
International Journal of Innovation, Creativity and Change. www.ijicc.net Volume 15, Issue 5, 2021

Hammoudeh, S.; Mensi, W.; Reboredoc, J. C.; \& Nguyen, D.; K. Dynamic dependence of the global Islamic equity index with global conventional equity market indices and risk factors. Pacific-Basin Finance Journal 2014, 30, 189-206.

Hasanhodzic \& A. Lo. Black's Leverage Effect is not due to Leverage'. SSRN Electronic Journal 2006, 1971(646).

Haughton, Y.; A.; and Iglesias, M.; E. Interest rate volatility, asymmetric interest rate pass through and the monetary transmission mechanism in the Caribbean compared to US and Asia. Economic Modeling 2012, 29, 2071-2089.

Hens \& S. Steude, The Leverage Effect without Leverage: An Experimental Study. Finance Research Letters 2009, 6(2):83-94.

Hkiri, B.; Hammoudeh, S.; Aloui, C.; \& Yarovaya, L. Are Islamic indexes a safe haven for investors? An analysis of total, directional and net volatility spillovers between conventional and Islamic indexes and importance of crisis periods. Pacific-Basin Finance Journal 2017, 43, 124-150.

Jayasuriya, et al. Asymmetric volatility in emerging and mature markets. Journal of Emerging Market Finance 2009, 8(1):25-43.

Jebran, K.; Chen, S.; \& Tauni, M.; Z. Islamic and conventional equity index comovement and volatility transmission: Evidence from Pakistan. Future Business Journal 2017, 3(2), 98106.

Joseph, L.; N, and Vezos, P. The sensitivity of US banks' stock returns to interest rate and exchange rate changes", Managerial Finance2006, 32, 182-199.

Kellner, F.; Lienland, B.; Utz, S. An a posteriori decision support methodology for solving the multi-criteria supplier selection problem. Eur. J. Oper. Res. 2019, 272, 505-522.

Khan, M.S.; Khan, K.I.; Mahmood, S.; Sheeraz, M. Symmetric and asymmetric volatility clustering Via GARCH family models: An evidence from religion dominant countries. Paradigms 2019, 13, 20-25.

Kirkulak Uludag B.; Khurshid M. Volatility spillover from the Chinese stock market to E7 and G7 stock markets. J Econ Stud 2019, 46: 90-105.

Koutmos, G., and Martin, A.D. (2003), "Asymmetric Exchange Rate Exposure: Theory and Evidence,” Journal of International Money and Finance, 22, pp.365-383.

Koutmos, G.; and Booth, G.; G. Asymmetric volatility transmission in international stock markets. Journal of International Money and Finance 1995, 14, 747-762. 
International Journal of Innovation, Creativity and Change. www.ijicc.net

Volume 15, Issue 5, 2021

Lintner, J. The valuation of risky assets and the selection of risky investments in stock portfolios and capital budgets. Review of Economics and Statistics, February 1965, 47, $13-3$.

Liow, H.K. Co-movements and correlations across Asian securitized real estate and stock markets. Real Estate Econ. 2012, 40, 97-129.

Lobo, J.; B. Asymmetric effect of interest rate changes on stock prices", The Financial review 2000, 35, 125-144.

Mandelbrot, B. The variation of certain speculative prices. Journal of Business 1963, 36, 394419.

Michel, B.; Candelon, B. Liberalisation and stock market co-movement between emerging economies. Quant. Financ. 2011, 11, 299-312.

Narayan, P.K.; Sharma, S.; S. Does data frequency matter for the impact of forward premium on spot exchange rate? Int. Rev. Financ. Anal 2015, 39, 45-53.

Oikonomou, I.; Platanakis, E.; Sutcli_e, C. Socially responsible investment portfolios: Does the optimization process matter? Br. Account. Rev. 2018, 50, 379-401.

Roni B.; Abbas G.; Wang, S. Return and Volatility Spillovers Effects: Study of Asian Emerging Stock Markets. J Syst Sci Inf 2018, 6: 97-119.

Ross, A, S.; Roll, R.; and Chen, F.; N. Economic Forces and the Stock Market. The Journal of Business 1986, 59, 383-403.

Sehgal S.; Pandey P.; Desisting F. Stock market integration dynamics and its determinants in the East Asian Economic Community Region. J Quant Econ 2018, 16: 389-425.

Shahzad, S. J. H.; Ferrer, R.; Ballester, L.; \& Umar, Z. Risk transmission between Islamic and conventional stock markets: A return and volatility spillover analysis. International Review of Financial Analysis 2017, 52, 9-26.

Sharpe, W. Capital asset prices: A theory of market equilibrium under conditions of risk. Journal of Finance, September 1964, 19, 425-42.

Sznajderska A. The role of China in the world economy: evidence from a global VAR model. Appl Econ 2019, 51: 1574-1587.

Talpsepp \& M. O.; Rieger. Explaining asymmetric volatility around the world. Journal of Empirical Finance 2010, 17(5):938-956. 
International Journal of Innovation, Creativity and Change. www.ijicc.net

Volume 15, Issue 5, 2021

Wang, K.; M. and Thi, T.; B.; N. Asymmetric pass-through and risk of interest rate: an empirical exploration of Taiwan and Hong Kong. Applied Economics2010,42, 659-670.

Zhou X.; Zhang W.; Zhang J. Volatility spillovers between the Chinese and world equity markets. Pac-Basin Financ J 2012, 20: 247-270. 